\title{
Severe macrophage activation syndrome. Is there a causative role for a homozygous A91V mutation in the perforin gene?
}

\author{
H Girschick*, R Rossi, U Kölsch, S Ammann, P Lohse, H Morbach, H von Bernuth, S Ehl
}

From 8th International Congress of Familial Mediterranean Fever and Systemic Autoinflammatory Diseases Dresden, Germany. 30 September - 3 October 2015

A 16 year old lebanese girl with consanguinous parents presented with a severe "abdominal" sepsis supposedly resulting from an infected vaginal tampon (ESBL E.coli). She had been healthy before. She developed severe hepatic functional disorder, infarction of the spleen, cardiovascular and renal insufficiency, as well as anemia and thrombocytopenia. Macrophage activation syndrome was diagnosed subsequently and systemic glucocorticoid treatment initiated. The girl recovered clinically. Of note, she developed severe cushingoid syndrome. Due to limited compliance she discontinued all anti-inflammatory medication (nsaids, gc and ciclosporin) 4 weeks later. The following 18 months inflammatory parameters were persistantly elevated $(E S R>100 \mathrm{~mm} / \mathrm{h})$. Familial mediteranean fever was excluded. Genetic analysis revealed a homozygous perforin I gene mutation 91 (GCG) -> Valin (GTG)/.pAla91Val-/A91V in exon 2. Familial hemophagocytic lymphohistiocytosis type II was discussed as a potential diagnosis. Perforin expression was diminshed to about $50 \%$ in NK-cells, however functional NK-cell cytotoxicity was in the lower normal range, considered not impaired.

On the basis of these findings, we want to discuss the role of the homozygous A91V perforin mutation for the initiation or perpetuation of a life-threatening macrophage activation syndrome, in addition to the further management of the patient.

\section{Consent to publish}

Written informed consent for publication of their clinical details was obtained from the patient/parent/guardian/ relative of the patient.

Vivantes Childrens Hospital Berlin, Pediatrics, Berlin, Germany
Published: 28 September 2015

doi:10.1186/1546-0096-13-S1-P20

Cite this article as: Girschick et al:: Severe macrophage activation syndrome. Is there a causative role for a homozygous A91V mutation in the perforin gene? Pediatric Rheumatology 2015 13(Suppl 1):P20.
Submit your next manuscript to BioMed Central and take full advantage of:

- Convenient online submission

- Thorough peer review

- No space constraints or color figure charges

- Immediate publication on acceptance

- Inclusion in PubMed, CAS, Scopus and Google Scholar

- Research which is freely available for redistribution 